\title{
Phenomenon-Based Perception Verbs in Swedish from a Typological and Contrastive Perspective ${ }^{1}$
}

\author{
Åke VIBERG \\ Uppsala Universitet \\ Ake.Viberg@lingfil.uu.se
}

\begin{abstract}
The article starts with a brief review of current studies of perception verbs as a background to the major part of the paper, which is devoted to a discussion of Phenomenon-based perception verbs. Three broad types are distinguished: sensory copulas, perceptibility verbs and sensory verbs. Verbs of these types appear across the five sense modalities. The categorization is tested on data from a translation corpus consisting of Swedish original novels translated into English, German, French and Finnish. The paper focuses on vision and audition, in particular the Swedish sensory copula verbs se ut "look" (e.g. "look happy") and låta "sound" and their translations. In the prototypical meaning, these verbs combine the reference to a sense modality with a modal or evidential component (roughly: SEEM). One of these components can be bleached to various degrees depending on the grammatical context. It turns out that French to a much greater extent than the other languages uses verbs that are unmarked for the sense modality. The place of the result within a general typological framework is briefly discussed. Perceptual verbs referring to an Experience such as see and hear follow a universal lexicalization hierarchy, whereas the structuring of Phenomenon-based verbs is typologically variable.
\end{abstract}

Résumé: Cet article commence par passer brièvement en revue les études actuelles des verbes de perception afin de contextualiser son propos, qui s'attache essentiellement aux verbes de perception orientés vers l'objet perçu. Trois grands types de verbes sont distingués: les copules sensorielles, les verbes de perceptibilité et les verbes sensoriels. Des verbes de ce type se rencontrent pour chacun des cinq sens. La classification est mise à l'épreuve des données issues d'un corpus de traduction, qui met en regard des romans suédois et leurs traductions en anglais, allemand, français et finnois. L'étude se concentre sur la vision et l'audition, en particulier sur les copules sensorielles du suédois se ut et låta et leurs traductions. Dans leur sens prototypique, ces verbes combinent une référence à un type de perception sensorielle et une composante modale ou évidentielle (schématiquement: SEMBLER). L'une de ces deux

1. I would like to thank three anonymous reviewers for fruitful critical comments and Rea Peltola and Flavie Feray for valuable comments on the analysis of Finnish and French. Remaining mistakes are my own responsibility. 
dimensions peut être neutralisée à des degrés divers en fonction du contexte grammatical. Il apparaît que le français a beaucoup plus que les autres langues recours à des verbes qui ne sont pas marqués pour ce qui est du type de perception sensorielle. La façon dont le résultat de l'étude s'inscrit dans un cadre typologique général est brièvement envisagée. Les verbes de perception référant à une expérience, comme voir ou entendre obéissent à une hiérarchisation lexicale universelle, alors que la structuration des verbes orientés vers l'objet perçu est typologiquement variable.

\section{Introduction}

This section gives a brief overview of selected aspects of the typology of verbs of perception in general as a background to the study of Swedish Phenomenon-based perception verbs referring to vision and audition, which will be discussed from a contrastive perspective in the following sections.

\subsection{The semantic field of perception verbs}

Table 1 (p. 19) presents a simple grid using English words as an illustration. Canonical verbs of perception like look/see and listen/hear obligatorily take an Experiencer as subject and refer to specific sense modalities, whereas Phenomenon-based verbs in various ways refer directly to what is perceived (the Phenomenon). Languages can make a distinction between Experiencer-based verbs that are Activities and Experiences. In English, different verbs are used for sight and hearing (look/see, listen/hear), but in some languages the distinction is signalled only grammatically (e.g. by using a dative subject to signal an Experience) and, in Australian languages, the distinction is usually not signalled at all (Evans \& Wilkins 2000).

There are several types of Phenomenon-based perception verbs. English has sensory copulas in all sense modalities where the Phenomenon is realized as subject and the Experiencer is optional: Ann looks happy (to me). In languages that have sensory copulas, these verbs are often - as in English - closely related to Experiencer-based verbs (in special constructions or by morphological derivation). The relationship between sensory copulas and ordinary copulas (primarily "to be") is complex, see Staniewski \& Gołębiowski (forthc.). In addition to sensory copulas, Swedish has verbs that indicate that a certain Phenomenon can be perceived, e.g. synas "be visible": Sjön syns (från balkongen) "The lake can be seen / You can see the lake (from the balcony)". The Phenomenon is realized as a subject, and there is an optional spatial adjunct that indicates the location of a potential Experiencer, which 
is not explicitly referred to. Verbs of this type are the major type of Phenomenon-based perception verbs in Finnish according to Huumo (2010), who has coined the term perceptibility verbs. The Finnish perceptibility verbs are morphologically related to the Experiencer-based verbs. The sensory verbs, which are exemplified in the rightmost column in Table 1, are usually not formally related to the canonical perception verbs. Sensory verbs describe a relatively "raw" sensation without introducing an Experiencer explicitly.

Table 1. The verbs of perception in English. A simple grid

\begin{tabular}{|c|c|c|c|c|c|}
\hline \multirow[b]{2}{*}{$\begin{array}{c}\text { Sense } \\
\text { modality }\end{array}$} & \multicolumn{2}{|c|}{ Experiencer-based } & \multicolumn{3}{|c|}{ Phenomenon-based } \\
\hline & Activity & Experience & $\begin{array}{l}\text { Sensory } \\
\text { copulas }\end{array}$ & $\begin{array}{c}\text { Percep- } \\
\text { tibility } \\
\text { verbs }\end{array}$ & $\begin{array}{c}\text { Sensory } \\
\text { verbs }\end{array}$ \\
\hline NEUTRAL & examine & $\begin{array}{l}\text { perceive, } \\
\text { notice }\end{array}$ & seem & $\begin{array}{l}\text { "be } \\
\text { noticeable" }\end{array}$ & \\
\hline SIGHT & look at & see & look & "be visible" & $\begin{array}{l}\text { shine, } \\
\text { shimmer, } \\
\text { glimmer, } \\
\text { gleam, } \\
\text { glitter, } \\
\text { glint, } \\
\text { glisten, } \\
\text { flash... }\end{array}$ \\
\hline HEARING & listen to & hear & sound & $\begin{array}{l}\text { "be } \\
\text { audible" }\end{array}$ & $\begin{array}{l}\text { crack, } \\
\text { creak, } \\
\text { rattle, } \\
\text { crash, } \\
\text { sough, } \\
\text { surge, } \\
\text { buzz... }\end{array}$ \\
\hline TOUCH & $\begin{array}{l}\text { feel, } \\
\text { touch }\end{array}$ & feel & feel & & $\begin{array}{l}\text { tickle, } \\
\text { abrade, } \\
\text { tingle, } \\
\text { sting, } \\
\text { burn, } \\
\text { smart... }\end{array}$ \\
\hline TASTE & taste & taste & taste & & \\
\hline SMELL & $\begin{array}{l}\text { smell (at), } \\
\text { sniff }\end{array}$ & smell & smell & & $\begin{array}{l}\text { stink, } \\
\text { reek }\end{array}$ \\
\hline
\end{tabular}


Several types of hierarchies have been proposed to account for lexicalization and associations between meanings within the field. Viberg $(1983,2001)$ presented a universal sense modality hierarchy for the lexicalization of (canonical) perception verbs (see Figure 1).

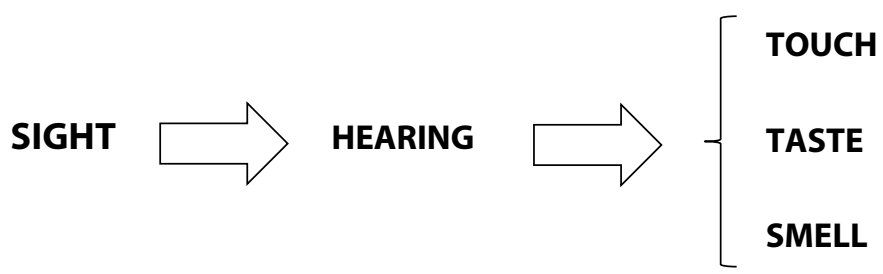

Figure 1. The sense modality hierarchy for perception verbs that are Experiences

The sense modality hierarchy, which applies primarily to Experiences, puts restrictions on lexicalization and on patterns of polysemy. There are languages such as Kobon (a Papua New Guinea language, see Viberg 1983: 150-152) that have one general verb of perception that does not seem to have a prototypical meaning tied to a specific sense modality, but most languages that have been described so far have at least one verb of that type. If a language has only one verb of perception that refers to a specific sense modality, it has SEE as its prototypical meaning. A common type of language has SEE and one more verb that covers the rest of the sense modalities. This verb tends to have HEAR as the prototypical meaning. This meaning is sometimes difficult to establish, but as long as it does not have a prototypical meaning referring to another sense than HEARING, the hierarchy is not contradicted (the language only has SEE). If a language has three or more perception verbs tied to a specific modality, it always has SEE and HEAR in addition to TOUCH, TASTE and / or SMELL. There are also more complex patterns, but, in general, verbs high (to the left) in the hierarchy tend to be lexicalized as simple verbs in more languages, tend to be more frequent, and tend to extend their meaning downwards (see Aikhenvald \& Storch 2013; Maslova 2004; San Roque et al. 2015; Wälchli 2016 for discussion and critique).

\subsection{Sensory verbs}

The sense modality hierarchy primarily applies to Experiences. As shown in Viberg (2015), there is great variability across languages with respect to the lexicalization of sensory verbs. Like many European languages, English has a large number of sensory light verbs such as 
gleam and glisten and of sensory sound verbs such as clatter, rattle and patter. The latter amount to more than a hundred different verbs in English as well as in Swedish (for a brief discussion, see Viberg 2015: 120-126). In stark contrast to the large sets of sensory light and sound verbs (see Section 2), European languages have few specialized verbs for taste and smell. However, these domains are richly elaborated in some non-European languages.

Elaborate systems of taste terms have been described for several African languages. Nakagawa (2012) describes two such elaborate fields in G|ui and G||ana, two Khoe languages spoken in Botswana (see Table 2). One field is referred to as elaborate taste verbs. Twenty verbs of this type have been attested (see Table 2.a for some typical examples).

Table 2. Examples of elaborate taste verbs

and food texture verbs in G|ui (based on Nakagawa 2012)

\begin{tabular}{|c|c|}
\hline \multicolumn{2}{|r|}{ a. Elaborate taste verbs ( 20 attested verbs) } \\
\hline Verb & Gloss \\
\hline ts hàà & "to have a bad taste typical of wildebeest meat" \\
\hline キhójõ & "to have a good taste typical of (ostrich) egg" \\
\hline g!úrō & "to have a good taste typical of parched wild melon seeds" \\
\hline !qX’ōrō & "to have a distinct taste of honey" \\
\hline cúm & $\begin{array}{l}\text { "to have a bad taste common to ostrich meat or certain } \\
\text { edible termites" }\end{array}$ \\
\hline & b. Food texture verbs ( 32 attested verbs) \\
\hline Verb & Meaning: "to have a certain texture like that of..." \\
\hline !húi !húì & "fruit full of juice" \\
\hline tsháǹ tshán & "tender fillet meat" \\
\hline g|úrà g|úrà & "steenbok meat lacking gravy" \\
\hline Xárù Xárù & "fresh tsamma melon" \\
\hline !úì !úì & "meat with much gravy" \\
\hline
\end{tabular}

Several of the elaborate taste verbs refer exclusively to a taste that is characteristic of a traditional type of food. The meanings thus have a high degree of specificity and another important feature is that they 
are not source based, i.e. derived from or etymologically related to the corresponding nouns that name the animals or plants, etc. that have the taste that the verb refers to. The food texture verbs are multimodal. Basically they refer to the experience of tactile features of a specific food or beverage, but often the characteristic sound arising through biting and chewing is a component of the meaning. Eighteen of the food texture verbs are derived from related ideophones and exhibit reduplication.

Elaborate systems of smell terms have also been found in non-European languages. The earliest documentation of such a system appears to be Aschmann's (1946) description of Totonac, a Totonacan language spoken in Mexico. In Totonac, there is no general word referring to smell but a choice must be made between eight different stems that refer to distinct types of smells as demonstrated in Table 3.

Table 3. Verb stems referring to eight categories

of smells in Totonac (based on Aschmann 1946)

\begin{tabular}{|ll|}
\hline \multicolumn{1}{|c|}{ Semantic category } & \multicolumn{1}{c|}{ Root } \\
\hline 1. Vegetation and good smells & $\mathrm{mu}^{2}{ }^{2}-\mathrm{u}^{2} \mathrm{n}$ \\
2. Bad smells & $\mathrm{pu}^{2}-$ \\
3. Medicinal and aromatic smells & $\mathrm{ha}-$ \\
4. Body and animal smells & $-\mathrm{un}-$ \\
$\begin{array}{l}\text { 5. Sour smells } \\
\text { 6. Smells that leave a taste in the mouth (e.g. of food } \\
\text { cooking) }\end{array}$ & $-\mathrm{u}^{2} \mathrm{t}-$ \\
$\begin{array}{l}\text { 7. Artificial smells (e.g. of perfume or hand soap) } \\
\text { 8. Air-permeating smells (e.g. a smell brought with the wind) }\end{array}$ & $\mathrm{kinkala}$ \\
\hline
\end{tabular}

More recently, olfaction and language have been extensively investigated in a number of studies from the Max Planck Institute for Psycholinguistics in Nijmegen (Majid et al. 2018a). Particularly interesting is the use of naming studies, for example Majid \& Burenhult (2014), who compared speakers of English with speakers of Jahai, an Aslian language with 12 distinct smell terms spoken in peninsular Malaysia. Speakers of Jahai found the naming of odours easy, whereas English speakers struggled with the same task (see also Jędrzejowski \& Staniewski forthc.; Viberg forthc. on olfactory verbs in Swedish). 
One sense remains to be discussed. The experience of sensations perceived in various ways with the skin are regarded as manifestations of the sense of touch and jointly referred to by feel in English. Phenomenon-based sensory words that describe such sensations more in detail form more specific semantic subfields such as texture, temperature and pain. In English adjectives are used to describe aspects of texture such as rough-smooth and hard-soft and to describe temperature (e.g. cold and warm). Temperature terms have been described in a broad typological survey covering 50 diverse languages (Koptjevskaja-Tamm 2015). The number of basic terms varied from one, in languages that only had a single word for cold/ cool, up to four in languages such as English that distinguish between cold and cool and warm and hot. Pain has also been studied typologically in a diverse set of languages. Reznikova et al. (2012) present a typological study of pain predicates based on data from more than 20 diverse languages. Verbs tended to be recruited from 4 semantic fields that describe the cause of the sensation, for example BURNING, which turned out to be the most frequent source (She felt a burning pain in her midriff).

The lexical elaboration of Phenomenon-based sensory verbs varies greatly across languages and thus represents a typologically variable feature. The present study is restricted to verbs. However, with respect to the set of semantic distinctions, sensory verbs in many respects resemble sensory words of other types such as adjectives and nouns. Recently, sensory words in general have attracted much interest. Strik Lievers \& Winter (2018) discuss how the encoding of sensory concepts varies across parts of speech. A related study by Winter et al. (2018) shows that vision dominates in English if all types of sensory words are taken into account but point out that this does not generalize across all cultures. In a broad and well-documented typological study based on 20 diverse languages, Majid et al. (2018b) show that the degree to which sensory domains are richly or poorly coded varies across languages: "For each perceptual modality, there are communities that excel at linguistic expression and those that seem to struggle to put them into words" (Majid et al. 2018b: 11374). The conclusion applies to (in my terminology) Phenomenon-based sensory words that describe sensory properties. It can still be maintained that Experiencer-based perception verbs, which focus on the perceiver rather than the sensory stimuli, follow (with only few exceptions) the universal sense modality hierarchy (see Figure 1 above). The first step has particularly strong support. As demonstrated in Viberg (2012), a verb meaning SEE is the most frequent perception verb in 12 European and 9 non-European languages. It is also one of the 20 most frequent verbs in all of these languages, 
which means that this verb holds a prominent position among basic verbs in general. The dominance of SEE gets strong support also from San Roque et al. (2015) in a study based on conversational data from 13 typologically diverse languages. San Roque et al. (2015: 55) conclude: "To summarize, talk about vision dominates conversation across diverse cultures, followed closely, but not universally, by hearing".

\subsection{This study: presentation of aims and the corpus}

Swedish makes many semantic distinctions between various types of Phenomenon-based visual and auditory perception verbs and provides a good starting-point for studying what characterizes such verbs from a cross-linguistic perspective. What are the basic semantic parameters? The following sections are devoted to a discussion of such verbs from a contrastive perspective. Literal and extended meanings of visual and auditory Experiencer-based verbs have already been studied in Viberg (2008) based on the Multilingual Parallel Corpus (see below) and across 13 typologically diverse languages in San Roque et al. (2018). See also Ibarretxe-Antuñano (2013) on perception metaphors across languages.

Section 2 is devoted to sensory verbs, Section 3 to sensory copulas and Section 4 to perceptibility verbs. Data for Section 2 will be taken from the English Swedish Parallel Corpus (ESPC) consisting of English and Swedish original texts together with their translations into the other language (Altenberg \& Aijmer 2000). Data for Sections 3 and 4 will be taken from the Multilingual Parallel Corpus (MPC), which at present consists of extracts from 22 Swedish novels and their translations into English, German, French and Finnish (around 600,000 words in the Swedish originals). Examples from this corpus will be marked by a text code based on the initials of the author's name (see the list of the works quoted at the end of the article). French turns out to be a particularly interesting language to compare with. Vinay \& Darbelnet ([1958] 1995: 53-56) state that English has a more diversified vocabulary than French to describe visual and auditory phenomena. Tegelberg (2000: 87-115) shows with data from a translation corpus that French has fewer such words than Swedish. Both these works discuss sensory light and sound verbs, whereas the present paper will focus on sensory copulas. Such verbs are compared in English and German with a focus on evidential meanings in Whitt (2010).

\section{Sensory light and sound verbs}

The MPC corpus is not large enough to allow a systematic contrastive study of the light and sound verbs. This section will primarily serve 
to identify the major semantic parameters that distinguish such verbs from sensory copulas and perceptibility verbs as a background to the more systematic study of these verbs in Sections 3 and 4 .

\subsection{Sensory light verbs}

Both English and Swedish have a number of sensory light verbs that describe the emission or reflection of light. The subject can appear in a Source-based construction and refer to the source which produces the light as in Swedish Solen skiner "The sun is shining", Lampan lyser "The lamp is shining" or Kolet glöder fortfarande "The coal is still glowing". In Swedish, the sensory light verbs - like other sensory verbs - characteristically appear in an impersonal construction that will be referred to as the Environmental construction as in Det lyser (i garaget) "The light is on (in the garage)", literally: "It shines (in the garage)". This construction obligatorily consists of an impersonal subject det "it" in combination with a sensory verb. Table 4 presents an overview of the sensory light verbs in Swedish. Timing is a major semantic parameter. The most general verbs lysa and skina refer to continuous light, whereas most of the other verbs refer to unsteady, frequentative light. (It is difficult to draw a sharp line, except for lysa and skina.) Often the frequentative verbs refer to reflected light as in (1).

1. Över kullerstenarna gnistrade det av gult och av rosa, trappan till stadshotellet skimrade av silver. (ESPC: Fiction)

The cobblestones sparkled yellow and pink and the steps up to the town hotel gleamed like silver.

Table 4. Sensory light verbs in Swedish

\begin{tabular}{|c|c|c|c|c|}
\hline \multicolumn{2}{|c|}{ Continuous } & \multicolumn{3}{|c|}{ Frequentative } \\
\hline lysa & & tindra & flimra & flamma \\
\hline skina & & skimra & skillra & \\
\hline glöda & glänsa & glimra & glimma & glimta \\
\hline stråla & & glindra & glittra & \\
\hline & blänka & gnistra & glinta & ulma \\
\hline
\end{tabular}

The frequentative verbs in Table 4 are sound symbolic or descriptive. The latter term, which takes the rather high degree of conventionalization into account, is used by Snell-Hornby (1983) in her contrastive study of English and German, which, like Swedish, have many such 
verbs, but there is little one-to-one correspondence. As in English, many of the sound-symbolic verbs begin with $g l$-in Swedish, but even if the verbs have a similar form, the degree of correspondence is low. Two or three of these verbs appear as translations of one of these verbs in the other language. The Swedish verb glittra is an example of this in (2) and (3). The contrasts between some of these verbs appear to be fuzzy even language-internally to native speakers.

2. Solen glittrade i den svagt krusade vattenytan. (ESPC: Fiction)

The sun was glistening on the rippling surface of the water.

3. Och när dimman lyfte glittrade det i fönstren där borta i New York. (ESPC: Fiction)

When the fog lifted the windows glittered over there in New York.

It appears that the translation relations between Germanic languages tend to be many-to-many. Judging from Tegelberg (2000: 95-112), the relation between Swedish and French to a greater extent tends to be many-to-one, even if French has a group of such verbs.

\subsection{Sensory sound verbs}

In many European languages, there is a relatively high number (around 100 in English and Swedish) of sensory sound verbs. It is possible to describe such verbs with reference to psychoacoustic properties such as low-pitched (buzz) and high-pitched (hiss), intensity or loudness (boom) or the temporal characteristics: continuous (sough), frequentative (rattle, clatter), and punctual (snap). Table 5 shows the system of temporal distinctions with examples in Swedish.

Table 5. A selection of sensory sound verbs in Swedish

\begin{tabular}{|l|lll|l|}
\hline Continuous & \multicolumn{3}{|c|}{ Frequentative } & Punctual \\
& \multicolumn{3}{|c|}{-ra + till } \\
\hline susa & knarra & knattra & knastra & fräsa till \\
fräsa & smattra & tjattra & kvittra & \\
väsa & muttra & puttra & huttra & \\
vina & slamra & klappra & skallra & \\
& mullra & bullra & dundra & \\
& klirra & knorra & surra & \\
& & & & \\
\hline
\end{tabular}


In Finnish, the temporal distinctions can be expressed systematically with derivational suffixes in sound verbs (Anttila 1976), see Table 6. What makes the number of sound verbs particularly large in Finnish is the possibility of forming sets of sound verb roots by varying the vowel between consonants as exemplified with one set of the continuous verbs in Table 6. Possible sources of the continuous sounds are shown to the left (Rea Peltola, personal communication).

Table 6. Examples of sensory sound verbs in Finnish

\begin{tabular}{|l|c|c|c|}
\hline \multicolumn{1}{|c|}{ Possible sources } & $\begin{array}{c}\text { Conti- } \\
\text { nuous } \\
\text {-ise- }\end{array}$ & $\begin{array}{c}\text { Frequen- } \\
\text { tative } \\
\text {-erta- }\end{array}$ & $\begin{array}{c}\text { Punctual } \\
\text {-ahta- }\end{array}$ \\
\hline $\begin{array}{l}\text { a hot sauna oven } \\
\text { kihistä }\end{array}$ & $\begin{array}{l}\text { nakertaa } \\
\text { a large amount of flies, bees, etc. }\end{array}$ & $\begin{array}{l}\text { kuhista } \\
\text { 'gnaw' }\end{array}$ & 'bang' \\
$\begin{array}{l}\text { the voice of a person who has a } \\
\text { cough }\end{array}$ & köhistä & \\
$\begin{array}{l}\text { the sound of water in rapids or } \\
\text { waterfall }\end{array}$ & kohista & \\
$\begin{array}{l}\text { speaking with a raspy voice } \\
\text { the sound of a newspaper or leaves } \\
\text { rubbing against each other }\end{array}$ & kähistä & \\
\hline
\end{tabular}

As an alternative (or rather complement) to the psychoacoustic description, it is possible to follow an ecological approach. The sounds can often be traced to particular sources and to typical events causing the sounds to emerge from the source. Typical situations can be studied in corpora, see (4):

4. Det knastrade som när man stekte fläsk. (MPC: MN)

There was a crackling, like pork frying.

Es knisterte wie Speck in der heißen Panne.

Ça grésilla comme quand on fait frire du lard.

This example also shows the use of the environmental construction, which is characteristic of sensory verbs in Swedish, German and French (see above on sensory visual verbs). Such constructions can also be used in English, although an existential construction is used in this example. The environmental construction is a kind of impersonal construction with a subject that has a low degree of referentiality and refers to 
perceptual characteristics of the whole scene. Like the visual sensory verbs, sound verbs can also be used in source-based constructions, where the subject refers to the source of the sound as in (5):

5. There are staircases, also of wood, which creak when we climb them. (ESPC: Fiction)

Det finns trappor, också de av trä, som knarrar när vi går uppför dem.

Intuitively, knarra has two prototypical sources in Swedish. One is dry wood such as in floorboards and wooden stairs, and the other is snow that crunches under the pressure of a boot. Such intuitions can be tested with large corpora, which make it possible to look systematically at collocates. In a Swedish corpus of fiction and social media texts (Korp: Bloggmix, Skönlitteratur; see Borin et al. 2012), the corresponding verb knarra can be studied with the help of a "word picture" (ordbild). The two most frequent nouns in the subject slot refer to floor (golv) and bed (säng). Snow (snö) has rank 5, if the words are ordered in descending frequency. The two most frequent adverbials refer to under shoe (under sko) and under foot (under fot), followed by in floor (i golv), in stairs ( $i$ trappa) and in house ( $i$ hus).

Information about typical sources is in many cases already given in good dictionaries, but, in order to give a complete description, information about psychoacoustic features are also needed. Sound verbs often have several translational correspondences that are difficult to keep apart. In spite of occurring only a few times in the ESPC, the verb creak is translated by three different Swedish verbs: knarra, knirka and $k n a k a$. For example, a wagon wheel can both knirka (as in 6) and knarra. Knirka appears to refer to a more high-pitched sound than knarra (said with the reservation that many of the sound verbs are subject to varied interpretations by native speakers).

6. Det började gnissla och knirka som av vagnshjul också. (ESPC: Fiction)

It started screeching and creaking like wagon wheels.

\section{Sensory copulas}

\subsection{Visual sensory copulas}

The subject of a sensory copula is a Phenomenon that is perceived by an Experiencer who is usually not explicitly mentioned, see (7): 


\section{Hon såg ledsen ut. (MPC: KE)}

She was looking unhappy.

Sie sah verdrossen aus.

Hän näytti surulliselta.

Elle avait l'air triste.

Swedish, like German, uses the verb meaning "see" in a special construction: se ADJ ut "see ADJ out", whereas English uses look ADJ and Finnish näyttää, which is derivationally related to nähdä "see", in combination with an adjective or a noun in the ablative case (-lta / -ltä). Another alternative is olla "be" + näköinen in combination with an adjective or a noun in the genitive. Näköinen is a denominal adjective (näkö "look; vision" + -inen, a suffix with an abstract meaning of possession and belonging), for example: Marja oli iloisen näköinen [Marja was happy-Gen näköinen] "Marja looked happy".

The sensory copulas discussed so far are transparently related to verbs meaning "see" or "look" and share the meaning component VISION, and one part of their meaning can be paraphrased "give a visual impression of being in a certain way". The interpretation of the most frequent French translation avoir l'air is not completely obvious. From a structural point of view, avoir l'air shows some signs to be developing into a lexicalized unit, since the adjective can optionally agree with the subject when it is animate rather than with the noun air, which is masculine: Elle avait l'air curieuse (f.) "She looked curious" (cf. Il avait l'air curieux (m.) "He looked curious"). However, the adjective obligatorily agrees with air in some contexts. (Elle a l'air sérieux (m.) comme un pape "She looks serious like a pope"). The basic meaning of French air is taken over from Latin aer, but the word has developed a secondary meaning (first attested in the $16^{\text {th }}$ century, in particular bel air "elegant manners"), which according to Rey (2010:43) is detached from the basic meaning and refers to the look or appearance of someone or something. Avoir l'air thus contains a reference to perception, to what can be observed but is not as clearly associated with vision as the visual sensory copulas discussed above.

In addition to the perceptual component, there is often an element of uncertainty in the sensory copulas (cf. She looked unhappy - She was unhappy). An emotion is an inner feeling that cannot be directly observed with the eyes but is presented as an inference based on visual evidence. The use of an auditory sensory copula (discussed in Section 3.2) refers to an inference based on auditory evidence (She sounded unhappy). Uncertainty could also be expressed with seem, but 
that leaves open what kind of evidence the assumption is based on. For simplicity, this meaning component will be referred to as SEEM (disregarding the contrast between near synonyms such as seem and appear). It should be noted that the sensory copulas can also be used to simply describe the appearance of something, for example: Mary has such a funny face. She looks happy even when she is sad. However, inferences are more or less involved in most examples where the visual copula is used to make a description. When we describe the visual properties of a certain object, we often use the ordinary copula: The coat is green. Colour is a visual characteristic, and it is not necessary to state that the description is based on vision. Under normal conditions a coat "has" a certain colour as an inherent property. The use of a sensory copula rather points to uncertainty or special conditions: The coat looks green but maybe it's too dark to see clearly. The green coat looks blue in this light.

A second frequent use of the visual copula is to express value judgments based on a personal opinion. Such judgments refer to some aspect of the visual appearance but do not normally express uncertainty. In all the languages in example (8), it would be possible to use an ordinary copula as in the French version, but an example such as Erica was fantastic does not specifically evaluate her looks but could also be used to express an opinion about what she said or did. The use of seem in examples of this type would indicate a lack of direct information to form a firm opinion (Erica seems to have been fantastic from what I've heard).

8. Erica såg som alltid fantastisk ut. (MPC: CL)

Erica looked fantastic, as always.

Erica sah wie immer phantastisch aus.

Erica näytti upealta, kuten aina.

Comme toujours, Erica était magnifique.

Table 7 (p. 31) shows the most frequent translations of se ut in the MPC corpus. The prototypical meanings of the verbs are indicated in the top row. The count includes cases where verbs combining the components SEEM + VISION are used with a more general meaning (see below). As can be observed, the most direct translations, which combine the meaning components SEEM and VISION in their prototypical meaning, dominate strongly in English and German, even though there are several translations that are unmarked for sense modality and only share the meaning component SEEM. In Finnish, näyttää dominates but the other expression related to vision olla näköinen is also relatively 
frequent. The most frequent French translation is avoir l'air "have the appearance/look", but, in French, there are several rather frequent translations that are neutral with respect to the sense modality. In addition, there is a greater variety of less frequent translations than in the other languages (see Other expressions in Table 7).

Table 7. The most frequent translations of Swedish se ut in the MPC corpus

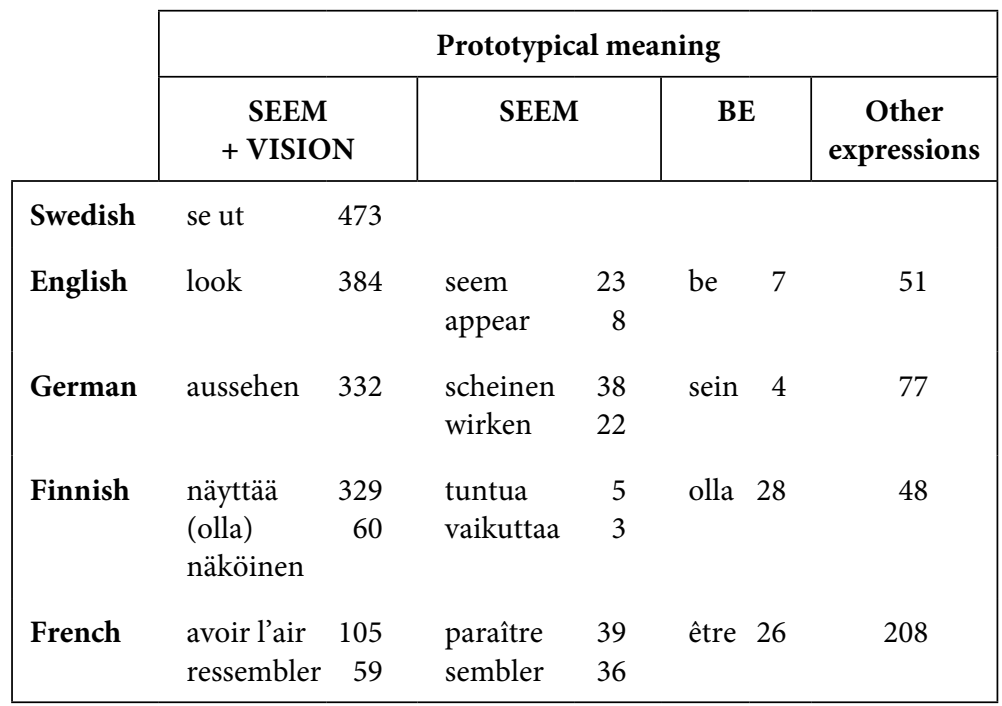

Se ut is used in several different constructions that affect the choice of translations. In Table 8 (p. 32), this is demonstrated for French, which has the most varied set of translations. The top row shows the type of complement that is characteristic of the construction. The use of an adjective or an adjectival participle as a complement (_ADJ), as described above, is by far the most frequent alternative in Swedish (259 out of 473 occurrences or 55\%). The dominant French translation in this case is avoir l'air, which, however, has a much lower frequency than the dominant translations in the other languages (French: 84/32\%; English: 213/82\%; German: 175/68\% and Finnish näyttää + näköinen: $178+45=223 / 69 \%+17 \%=86 \%)$.

The second most frequent complement of se ut is som $+\mathrm{N}(\mathrm{NP})$. This construction serves to make comparisons as in (9). Som is an indeclinable particle with many functions, the most frequent of which is as a relative marker. In combination with se ut, it marks the standard of comparison (cf. Eva är lika lång som Lisa "Eva is as tall as Lisa"). The dominant French translation in this use is ressembler "to resemble, be like". 
Table 8. Phenomenon-based constructions with se ut and their French correspondences

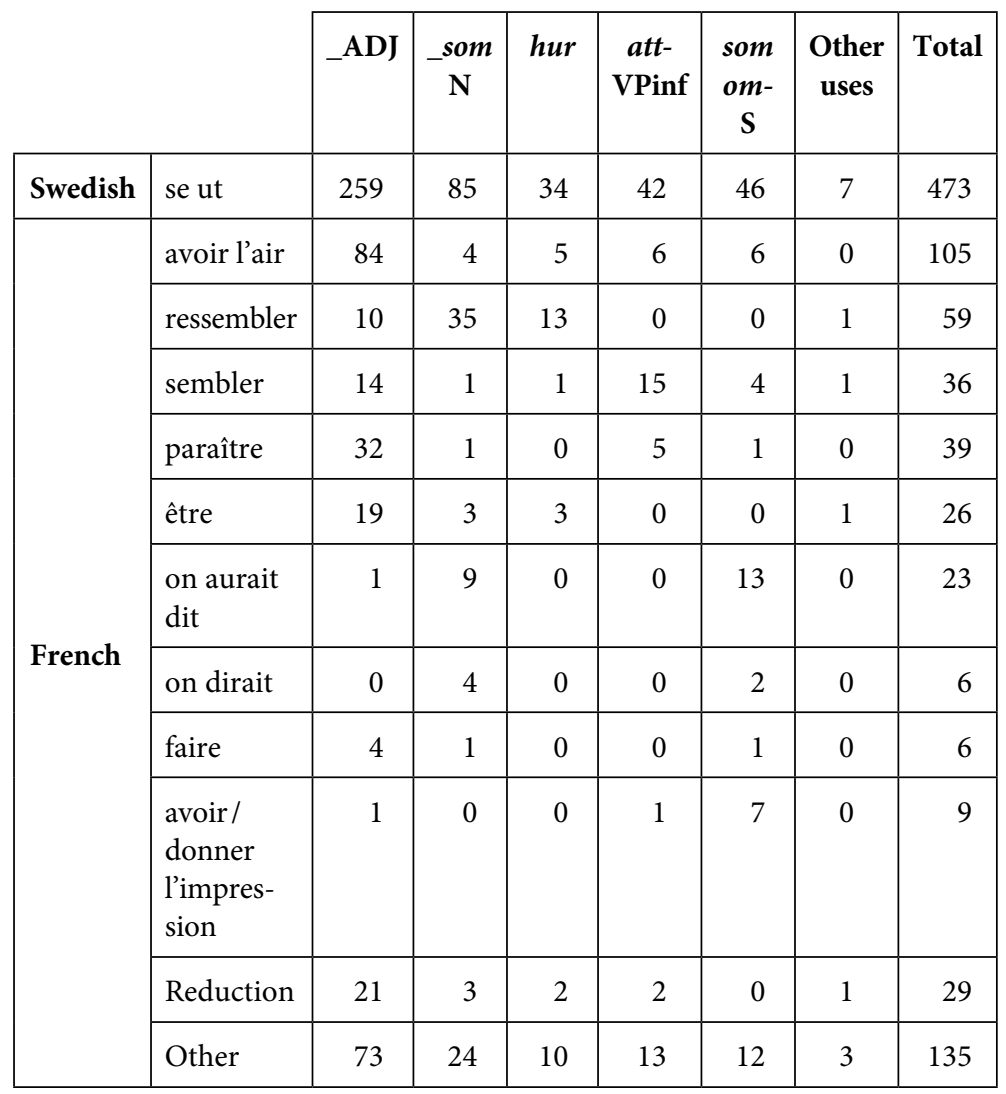

9. Men jag ser inte ut som en baby. (MPC: PCJ2)

But I don't look like a baby.

Aber ich sehe nicht aus wie ein Baby.

Mutta minä en todellakaan näytä vauvalta. (Ablative)

Mais je ne ressemble pas à un bébé.

Examples with hur "how" have been singled out as a special case in Table 8, since hur covers descriptions that could be made both with_ADJ and_som $\mathrm{N}$. The most frequent translation in French is ressembler even in this case, whereas the other languages in most cases use the most direct translation (see 10). 
10. Hur såg Marty ut innan han kom i puberteten. (MPC: PCJ) What had Marty looked like before he reached puberty. Wie sah Marty Feldman aus, bevor er in die Pubertät kam. Minkä näköinen Marty oli mahtanut olla ennen kuin tuli murrosikään.

À quoi ressemblait Marty avant d'entrer dans la puberté?

When se ut has an infinitive construction as complement (att-VPinf), the other languages except Finnish often use a verb meaning SEEM as translation (see 11).

11. Havel såg ut att fundera. (MPC: $\mathrm{HN}$ )

Havel appeared to be thinking.

Havel schien nachzudenken.

Havel näytti harkitsevan.

Havel parut réfléchir.

In the Swedish example, the supposition that Havel is thinking is presented as an inference based on visual information (e.g. that Havel is knitting his brows). This holds for most of the 42 examples where se $u t$ has an infinitive as complement, but in some examples such as (12) a visual element is difficult to trace, and the statement is presented as an inference based on general conceptual information.

12. De riktiga författarna ser $u t$ att veta allting. (MPC: TL)

Real writers seem to know everything.

Die richtigen Schriftsteller scheinen alles $z u$ wissen.

Oikeat kirjailijat näyttävät tietävän kaiken.

Les véritables écrivains semblent tout savoir.

In French, the most frequent translation of se ut with an infinitival complement is sembler "seem" (15 occurrences) followed by avoir l'air (6) and paraître "appear, seem" (5). In English, look (21) alternates with seem (14) and appear (4), whereas Finnish mostly uses the dominant translation näyttää (32) in combination with a participial construction (described in Karlsson 2008: 279). In German, scheinen "seem" is the most frequent translation used in 26 examples. In 10 examples aussehen is used but always with restructuring of the complement, usually a subjunctive clause introduced with als-S as in (13): 
13. Hon såg $u t$ att vara vid gott mod. (MPC: POE)

She seemed to be in good heart.

Sie sah aus, als sei sie guten Mutes.

Hän näytti olevan hyvällä tuulella

Elle avait l'air de bonne humeur.

German scheinen is interesting because it is originally a light-source verb and still can be used as such: Der Mond scheint "The moon is shining". As demonstrated in the thorough analysis of scheinen used with a $z u$-infinitive in Diewald \& Smirnova (2010: 177-191), the verb can refer to accessible evidence of an unspecified type but still in certain contexts specifically refers to visual evidence.

Se ut can be used with a sentential complement introduced with som om or sometimes som att or only som (see 14). All these variants are represented as som om-S in Table 8. A further characteristic is that se ut often appears in an impersonal construction with det "it" as a subject.

14. Ett ögonblick såg det $u t$ som om han tänkte fly. (MPC: MN)

For a moment it looked as if he might run away.

Einen Augenblick lang sah es aus, als wollte er fliehen.

Hetken näytti siltä kuin hän olisi ollut aikeissa paeta.

Un instant, on aurait dit qu'il avait l'intention de s'enfuir.

Most of the examples refer to imagined or other irrealis situations as in (14), which is often reflected in the form of the verb in the sub-clause in German (subjunctive) and Finnish (conditional mood, Karlsson 2008: 237). The major correspondent of se ut dominates as a translation except in French (out of a total of 46: English: look 37, seem 2, appear 2; German: aussehen 35, scheinen 5, wirken 2; Finnish: näyttää 33, olla näköinen 2, olla "be" 3, tuntua "feel, seem" 3). In French, the most frequent correspondent is an impersonal construction with on: on aurait dit que "one could have said that-S”, which signals irrealis or uncertainty. The most direct correspondent avoir l'air is also used but requires restructuring in the form of an infinitive complement as in (15):

15. På avstånd såg det ut som om vi var tungt beväpnade. (MPC: JM) At a distance it looked as if we were heavily armed.

Aus der Entfernung sah es so aus, als ob wir schwer bewaffnet wären. Matkan päästä näytti siltä niin kuin me olisimme olleet raskaasti aseistettuja.

À distance, nous avions l'air d'être lourdement armés. 
The expression se ut som om-S can also be used in a counterfactual context as in (16):

16. Erika, jag kommer inte att lämna Millennium, men det är viktigt att det ser ut som om jag har gjort det. (MPC: SL)

Erika, I'm not going to leave Millennium, but it's important for it to look as if I have.

Erika, ich werde Millennium nicht verlassen, aber es muss so aussehen, als ob.

Erika, minä en jätä Millenniumia, mutta on tärkeää, että näyttää siltä kuin olisin jättänyt.

Erika, je ne vais pas quitter Millénium, mais il est important que les gens en aient l'impression.

French in this example uses avoir l'impression with les gens "people" as a kind of impersonal subject. This example shows how support verb + noun can be used with another noun than air as a translation of se ut. The same noun can also be used with "give": donner l'impression. Another type of restructuring in French is reduction as in (17), where the verb is omitted. Most frequently l'air is involved (12 of 29 examples).

\section{Men så hejdade han sig och såg rädd ut. (MPC: MN)}

But then he would change his mind and look scared.

Mais alors il s'arrêtait, l'air peureux.

To sum up, English, German and Finnish have rather close equivalents to the sensory copula se $u$, which with a few exceptions noted above are used as translations across different constructions and functions of se ut. In French, avoir l'air is the most frequent translation, but it is not as dominant as in the other languages ( $43 \%$ of the translations vs. $71 \%-86 \%)$. The type of construction in which se ut is used influences the choice of translation more in French than in the other languages. Verbs meaning SEEM are used as translations in all the languages but to various degrees. This reflects the fact that the visual sensory copula has a prototypical meaning that includes the semantic components VISION + SEEM. At the same time, the visual copula has a tendency across languages to be used as a general marker of modality or evidentiality without referring to a specific sense modality. A more detailed analysis of modality and evidentiality would be interesting but requires a separate study. 


\subsection{Auditory sensory copulas}

Swedish has a sensory copula associated with audition, namely låta. The most frequent complement of läta in this use is an adjective or a past participle as in example (18), which shows translations into Norwegian and Danish in addition to the other MPC languages referred to in this paper:

18. Swedish: Henrik Wijkner hade låtit sympatisk i telefon. (MPC: CL) English: Henrik Wijkner had sounded pleasant on the telephone. Norwegian: Henrik Wijkner hadde hørtes sympatisk $u t$ i telefonen. Danish: Henrik Wijkner havde lydt sympatisk i telefonen.

German: Henrik Wijkner hatte am Telefon sympathisch geklungen. Finnish: Henrik Wijkner oli kuulostanut puhelimessa oikein mukavalta.

French: Henrik Wijkner lui avait paru sympathique au téléphone.

The Swedish verb lata is etymologically related to the Latin verb laxāre. Reflexes of this verb are used as a verb of letting causation in Swedish and the other present-day Germanic languages (e.g. English let, German lassen) as well as in the Romance languages (e.g. French laisser, Spanish dejar). In addition, these verbs have developed various more language-specific uses (Viberg 2009; see Rawoens 2008 and Levshina 2016 for a detailed discussion of the causative uses). The use of the verb of letting as a sensory copula is very language-specific. Danish uses lyde (related to the noun lyd "sound") and Norwegian høres ut "be heard out" (alternating with låte). The German verb klingen is also clearly associated with sound (e.g. the frequentative klingeln: Das Telefon klingelt "The telephone rings") as well as the Finnish verb kuulostaa, which is derivationally related to kuulla "hear". In example (18), French uses paraître "seem", which is not associated with audition. Table 9 (p. 37) shows the most frequent translations of the 170 occurrences of copulative låta in the MPC corpus. As can be observed, English and Finnish have one dominant correspondence (the verb used in example 18). That also applies to German, even though klingen alternates with the less frequent sich anhören. French, on the other hand, lacks any close correspondence. The most frequent translations are paraitre "seem", être "be" and sembler "seem", which are not associated with sound. The verb sonner is derivationally related to the noun son "sound" and is frequently used as a sound-source verb that has a sound source as subject and refers to the emission of a sound without any further 
complement (La cloche / le téléphone sonne "The bell / the telephone rings"). The use of latta as a pure sound-source verb is very restricted in present-day Swedish. Sonner can also be used as a sensory copula, for example Ses mots sonnaient étranges au téléphone "Her words sounded strange on the telephone" or Ça sonne bien! (ce que tu me dis). "That sounds good! (what you are telling me)". (I thank Flavie Feray, for these examples.) However, judging from the few examples in Table 9, sonner is only weakly established as a sensory copula.

Table 9. The translations of Swedish låta as an auditory copula

\begin{tabular}{|c|c|c|c|c|c|c|c|c|}
\hline & \multicolumn{8}{|c|}{ Prototypical meaning } \\
\hline & SEEM + SOU & UND & SEEM & & BE & & $\begin{array}{c}\text { SOUND, } \\
\mathbf{N}\end{array}$ & $\begin{array}{c}\text { Other } \\
\text { expres- } \\
\text { sions }\end{array}$ \\
\hline Swedish & låta & 170 & & & & & & \\
\hline English & sound & 143 & seem & 4 & be & 5 & 6 & 12 \\
\hline German & $\begin{array}{l}\text { klingen } \\
\text { sich anhören }\end{array}$ & $\begin{array}{r}119 \\
15\end{array}$ & wirken & 4 & sein & 5 & 5 & 22 \\
\hline Finnish & kuulostaa & 134 & tuntua & 6 & olla & 7 & 4 & 19 \\
\hline French & sonner & 7 & $\begin{array}{l}\text { paraître } \\
\text { sembler }\end{array}$ & $\begin{array}{l}24 \\
12\end{array}$ & être & 22 & 16 & 89 \\
\hline
\end{tabular}

The lack of a direct equivalent in French motivates concentrating on that language. Table 10 (p. 38) shows how the French translations are distributed across the complements of lata. The top row shows the frequency of the complements of copulative Swedish låta. The use with an adjective or participle as complement (_ADJ) dominates strongly, followed by the use with som as a marker of comparison in combination with a noun / NP (_som $\mathrm{N}$ ).

Apart from the fact that avoir l'air has a much lower frequency, the French translation pattern of låta is similar to the one of se ut. The most frequent translations of låta in the context_ADJ are paraitre "seem", être "be" and sembler "seem", all of which lack any reference to a sense modality. It is also the case that these three translations primarily are used in the context_ADJ. Avoir l'air, which is the most frequent translation of the visual sensory copula se $u t$, also appears as a translation, but only 5 times.

The auditory copula has several functions. It can be used to describe acoustic properties of a sound as in (19). 
Table 10. French translations of copulative låta across different types of complements

\begin{tabular}{|c|c|c|c|c|c|c|c|c|}
\hline & & & & & & & \\
\hline & & _ADJ & som $\mathrm{N}$ & hur & $\begin{array}{c}\text { som } \\
\text { om-S }\end{array}$ & $\begin{array}{c}\text { som } \\
\text { när } \\
-S\end{array}$ & $\begin{array}{c}\text { Other } \\
\text { uses }\end{array}$ & Total \\
\hline Swedish & låta & 107 & 30 & 8 & 14 & 3 & 8 & 170 \\
\hline \multirow{12}{*}{ French } & sonner & 5 & 2 & 0 & 0 & 0 & 0 & 7 \\
\hline & $\begin{array}{l}\text { avoir } \\
\text { l'air }\end{array}$ & 5 & 1 & 0 & 0 & 0 & 0 & 6 \\
\hline & paraître & 22 & 0 & 0 & 0 & 0 & 2 & 24 \\
\hline & être & 20 & 1 & 0 & 0 & 0 & 1 & 22 \\
\hline & sembler & 6 & 0 & 0 & 1 & 0 & 0 & 7 \\
\hline & $\begin{array}{l}\text { ressem- } \\
\text { bler }\end{array}$ & 1 & 2 & 0 & 0 & 1 & 1 & 5 \\
\hline & faire & 4 & 2 & 2 & 0 & 0 & 0 & 8 \\
\hline & $\begin{array}{l}\text { on aurait } \\
\text { dit }\end{array}$ & 0 & 6 & 0 & 4 & 0 & 0 & 10 \\
\hline & $\begin{array}{l}\text { dire } \\
\text { other* }\end{array}$ & 0 & 2 & 0 & 2 & 0 & 0 & 4 \\
\hline & $\begin{array}{l}\text { avoir } \\
\text { l'impres- } \\
\text { sion }\end{array}$ & 2 & 1 & 0 & 3 & 0 & 0 & 6 \\
\hline & $\begin{array}{l}\mathrm{N}_{-} \\
\text {SOUND }\end{array}$ & 13 & 1 & 1 & 0 & 0 & 1 & 16 \\
\hline & Other & 29 & 12 & 5 & 4 & 2 & 3 & 55 \\
\hline
\end{tabular}

*on dirait: 3, autrement dit: 1

19. Rösten lät skrovligare än hon önskat. (MPC: LM)

Her voice sounded rougher than she would have wanted.

Ihre Stimme klang rauher als gewollt.

Ääni kuulosti käheämmältä kuin hän olisi toivonut.

Sa voix était plus rauque qu'elle ne l'aurait voulu. 
Another function is to make an evaluative judgment of the sound. In example (20) a character describes his first attempt to sing:

20. Jag gol och pep, och det lät värre än hunden. (MPC: MN)

I crowed, I whined and it sounded worse than the dog.

Ich johlte und quiekte, es klang schlimmer als ein Hund.

Minä kieuin ja piipitin, se kuulosti vielä koiran ulvontaakin kamalammalta.

Je hurlais et piaillais. C'était pire qu'un chien.

It is worth noticing that the auditory copula is frequently used to form an evaluative judgment of the content of what is said. This is clearly reflected in the French translation ("the idea") of (21). Actually, the auditory copula can be used to evaluate verbal content in general even when it is presented in written form. You can say The new proposal sounds interesting, even when the proposal has been presented in a letter.

21. Det lät genialiskt. (MPC: KÖ)

That sounded brilliant.

Das klang genial.

Se kuulosti nerokkaalta.

L’idée paraissait géniale.

Like the visual copula, lata can be used to signal that an inference is made, based on auditory evidence in this case. (22) is an example of a clearly evidential use of làta. The Finnish and French translations lack reference to auditory evidence, but in the case of Finnish this is an exception.

22. Jag vet inte... kanske att hon lät mera uppgiven än rädd, egentligen. (MPC: HN)

I don't know... Perhaps that she sounded more resigned than scared, in fact.

Ich weiß nicht... vielleicht, daß sie sich eher resigniert angehört hatte als ängstlich.

En tiedä... ehkä että hän tuntui oikeastaan olevan pikemminkin alistunut kuin peloissaan.

Je ne sais pas... peut-être qu'elle était plutôt à bout... pas qu'elle avait réellement peur. 
Summing up, the auditory copula låta has close correspondences in English, German and Finnish and tends to be translated with an auditory copula across different constructions and functions. French largely lacks an auditory copula. The major candidate, sonner "sound", is only used a few times as a translation. Sense modality sometimes is signalled with nouns referring to sound in combination with a support verb. Apart from that, French uses the same verbs as the ones that are used to translate se ut, except for avoir l'air, which only translates låta a few times.

\section{Perceptibility verbs}

Perceptibility verbs have a potential meaning component and refer to what can be perceived with the senses. Swedish has four such verbs: synas "be visible", höras "be audible" and kännas "be possible to feel" and a verb that is neutral with respect to the sense modality: märkas "be noticeable". As mentioned, such verbs are basic in Finnish according to Huumo (2010), but it turns out that they lack a direct equivalent in the other three languages. From a formal point of view, the Swedish perceptibility verbs are passive verbs with the passive suffix $-s$ added at the end. From a functional point of view, the perceptibility verbs differ from canonical passives by not allowing an explicit Agent (or Experiencer). Such verbs imply a generalized Experiencer and basically describe what could be observed by anyone who potentially is present in the situation talked about. A typical example is (23):

23. Det syns på kartorna. (MPC: TL) (det “it" refers to a mountain)

You can see it on the maps.

Auf den Karten ist er $z$ u sehen.

Se näkyy kartoissa.

Il se voit sur les cartes.

The visual perceptibility verb synas has a regular passive form, an added $-s$, but its tense forms are irregular. The active form syna "examine (by eye)" is only loosely related to the perceptibility verb since it is inflected as a regular verb both when it is active and when it is passive.

The most frequent translations of both the visual and the auditory perceptibility verbs are shown in Table 11 (p. 41). The most frequent translation of synas in English is be seen, the passive form of see, usually in combination with can. In (23), an active form is used with you as a generic subject. The potential meaning of synas and höras is reflected in 
the frequent use of can in the English translations but the interpretation would deserve further discussion than what can be provided here. There is a general tendency to combine English verbs referring to perceptual experiences with can (see e.g. Gilbert 1987: 274-276).

Be visible is also relatively frequent (see example 24). German uses as special construction $z u$ sehen sein "be to see" as in (23). A relatively frequent alternative is sehen with the impersonal subject man. French has no dominant translation, but the two most frequent translations are voir "see" in a reflexive (middle) construction (se voir) as in (23) or in a construction with impersonal on as subject as in (24). Only Finnish uses a perceptibility verb as the dominant translation, namely näkyä as in (23). This verb is derived from the stem näke- "see" with the detransitivizing suffix $-y /-u$, which forms several types of intransitive verbs (see Hellerstedt \& Peltola 2019, for a description of this suffix). Occasionally, a passive form of "see" is used as in (24):

24. På vissa platser syntes igår tre solar samtidigt på himlen. (MPC: TL) In some places yesterday three suns were visible in the sky simultaneously.

An einigen Orten waren gestern gleichzeitig drei Sonnen am Himmel zu sehen.

Eilen nähtiin joissakin paikoin taivaalla kolme aurinkoa yhtä aikaa.

Hier, à certains endroits, on a pu observer trois soleils en même temps dans le ciel.

Table 11. The most frequent translations

of Swedish synas and höras in the MPC corpus

\begin{tabular}{|l|lrlll|}
\hline Swedish verbs & \multicolumn{1}{c|}{ synas } & 65 & \multicolumn{1}{c|}{ höras } & 102 \\
\hline \multirow{2}{*}{ English } & (can) be seen & 21 & (can) be heard & 47 \\
& be visible & 13 & Exp. + (can) hear & 24 \\
German & zu sehen sein & 27 & zu hören sein & 51 \\
& man + sehen & 13 & man + hören & 18 \\
\multirow{2}{*}{ Finnish } & näkyä & 42 & kuulua & 78 \\
& & & Exp. + kuulla & 4 \\
\multirow{4}{*}{ French } & on + voir & 10 & on + entendre & 36 \\
& se voir & 7 & Exp. + entendre & 14 \\
& apparaître & 6 & & \\
\hline
\end{tabular}


From a formal point of view, the Swedish auditory perceptibility verb höras is the regular passive form of höra "hear" with the passive suffix -s. From a functional perspective, it is special, since it does not allow an explicit Experiencer, but rather implies a non-referential or generalized Experiencer (anyone potentially present in the situation talked about). Since höras is discussed in Hellerstedt \& Peltola (2019), this verb will be commented on only briefly. As can be observed in Table 11, the same types of constructions are used with the verb meaning "hear" as were used with the visual copula. A representative example is shown in (25):

25. Inga röster hördes. (MPC: KE)

No voices could be heard.

Stimmen waren nicht $z u$ hören.

Ihmisääniä ei kuulunut.

On n'entendait aucune voix.

The Finnish auditory perceptibility verb kuulua is derived from the stem kuul- "hear" with the suffix $-y /-u$ in the same way as näkyä "be possible to see”. It strongly dominates as a translation. In English and French, an Experiencer-based expression is often used as a translation with an Experiencer that has specific reference and is derived from the context (Exp. + hear/entendre in Table 11). Both English and French have such constructions in (26):

26. "En liten rar visa”, hördes försynt från korridoren. (MPC: KÖ)

"A sweet little song," I heard faintly from the corridor.

»Ein nettes, kleines Liedchen«, klang es taktvoll aus dem Flur.

"Pienen herttaisen laulun", kuului kaino ääni käytävästä.

"Une gentille petite chanson", l'entendis-je ajouter d'une voix timide dans le couloir.

In combination with an impersonal det "it" as subject and a that-S clause, the Swedish perceptibility verbs can be used to express factivity as in (27). Only Finnish has a direct equivalent, the perceptibility verb näkyä. The major structural difference is that Finnish does not have an impersonal subject.

27. Det syntes att hon hela tiden tänkte på honom. (MPC: KE)

It was clear she was thinking about him all the time.

Man sah, daß sie unablässig an ihn dachte. [One saw, that-S]

Näkyi että hän ajatteli miestä koko ajan.

Et l'on voyait qu'elle ne cessait de penser à lui. 
The use of the perceptibility verbs with a that-S complement forms a parallel to the use of the sensory copulas with an as if-complement in Swedish as demonstrated in Table 12. (Känns is the passive form of känna "feel" in the present tense and på smaken / på lukten means "on the taste" / "on the smell".)

Table 12. Sentential complements of Swedish sensory copulas and perceptibility verbs

\begin{tabular}{|c|c|}
\hline 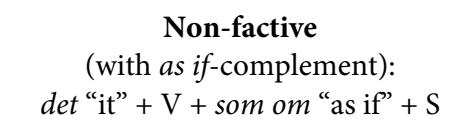 & 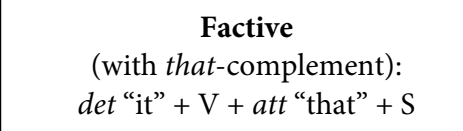 \\
\hline $\begin{array}{l}\text { Det verkar som om Per är arg. } \\
\text { "It seems as if Per is angry." }\end{array}$ & $\begin{array}{l}\text { Det märks att Per är arg. } \\
\text { "It is obvious that Per is angry." }\end{array}$ \\
\hline $\begin{array}{l}\text { Det ser ut som om Per är trött. } \\
\text { "It looks as if Per is tired." }\end{array}$ & $\begin{array}{l}\text { Det syns att Per är trött. } \\
\text { "You can see that Per is tired." }\end{array}$ \\
\hline $\begin{array}{l}\text { Det låter som om Per är ledsen. } \\
\text { "It sounds as if Per is sad." }\end{array}$ & $\begin{array}{l}\text { Det hörs att Per är ledsen. } \\
\text { "You can hear that Per is sad." }\end{array}$ \\
\hline $\begin{array}{l}\text { Det känns som om benet är brutet. } \\
\text { "It feels as if the bone is broken." }\end{array}$ & $\begin{array}{l}\text { Det känns att benet är brutet. } \\
\text { "You can feel that the bone is } \\
\text { broken." }\end{array}$ \\
\hline $\begin{array}{l}\text { Det smakar som om grädden är sur } \\
\text { i tårtan. } \\
\text { "It tastes as if the cream is sour in } \\
\text { the cake." }\end{array}$ & $\begin{array}{l}\text { Det känns på smaken att grädden } \\
\text { är sur. } \\
\text { "You can taste that the cream is } \\
\text { sour." }\end{array}$ \\
\hline $\begin{array}{l}\text { Det luktar som om det brinner. } \\
\text { "It smells as if it is burning." }\end{array}$ & $\begin{array}{l}\text { Det känns på lukten att det brinner. } \\
\text { "You can smell that it is burning." }\end{array}$ \\
\hline
\end{tabular}

\section{Conclusion and discussion}

Verbs referring to perceptual Experiences follow a universal lexicalization hierarchy with SEE at the top, followed by HEAR, whereas Phenomenon-based perception verbs are typologically variable. Verbs typically have a human subject (topic) and refer to situations where humans act on or Experience their environment. The dominance of SEE is biologically and cognitively grounded. Overall, we rely more on vision than on other senses, even if this does not hold in all situations (e.g. Viberg 2001: 1306-1307; Stokes \& Biggs 2015; Winter et al. 2018: 214). Phenomenon-based sensory words (including verbs) refer more directly to the environment and describe it more in its own terms. (In certain cosmologies, the environment/ nature acts on humans.) In this area, there is greater typological variation (Majid et al. 2018b). 
Sensory copulas and perceptibility verbs, which have been studied in this paper, are an example of that variability. Many languages do not have this type of verbs but such verbs can be found even outside Europe (e.g. in several Bantu languages such as Setswana, see Viberg 2001: 1299). The study shows that English, German and Finnish have visual and auditory copulas that are used as translations of se $u t$ and låta in the majority of cases, whereas the corresponding sensory copulas are weakly developed in French, in particular in the auditory domain. Perceptibility verbs are found in Swedish and Finnish but not in the other three languages studied. From a typological perspective, the following tentative conclusions can be drawn:

- Phenomenon-based perception verbs are of at least three different types (though typological studies may turn up more types): sensory copulas, perceptibility verbs and sensory verbs.

- The existence of such verbs is a typologically variable feature.

- Sensory copulas and perceptibility verbs refer primarily to a certain sense modality (like Experiencer-based verbs) and tend to develop modal and/ or evidential meanings.

- These two types of verbs develop from canonical verbs of perception in special constructions, often in a derived form. Sensory copulas can also develop out of sensory light and sound verbs (e.g. German scheinen, klingen).

- Sensory verbs allow much more semantic elaboration than sensory copulas and perceptibility verbs. Intensity and evaluation are prominent. In addition, there is a wide range of values along parameters that are tied to the qualities of a specific sense modality.

- Sensory verbs tend to be based on sound symbolism (of various types). Reduplication is also common.

- In the languages studied in this paper, there are relatively many sensory light verbs but an even greater number of sensory sound verbs. This imbalance is probably a universal tendency due to the preponderance of sound symbolism, but this conjecture needs to be corroborated in studies based on typologically diverse languages. Many languages have a special class of ideophones that are not verbs.

- European languages typically have a restricted number of verbs referring to taste and smell, but this is a typologically variable feature. Richer systems can be found in languages outside Europe. 


\section{References}

\section{Studies}

Aikhenvald A. Y., Storch A. (eds.) (2013), Perception and Cognition in Language and Culture, Leiden - Boston, Brill.

Altenberg B., Aijmer K. (2000), “The English-Swedish Parallel Corpus: A Resource for Contrastive Research and Translation Studies", in Corpus Linguistics and Linguistic Theory, C. Mair, M. Hundt (eds.), Amsterdam - Atlanta, Rodopi, p. 15-23.

AntTila R. (1976), "Meaning and Structure of Finnish Descriptive Vocabulary", in Papers from the Transatlantic Finnish Conference, R. T. Harms, F. E. Karttunen (eds.), Austin, The University of Texas, p. 1-12.

Aschmann H. P. (1946), “Totonac Categories of Smell”, Tlalocan, vol. 2, no. 2, p. 187-189.

Borin L., Forsberg M., Roxendal J. (2012), “Korp - The Corpus Infrastructure of Språkbanken”, on line: http://www.lrec-conf.org/proceedings/ lrec2012/pdf/248_Paper.pdf.

Diewald G., Smirnova E. (eds.) (2010), Evidentiality in German: Linguistic Realization and Regularities in Grammaticalization, Berlin, De Gruyter Mouton.

Evans N., Wilkins D. (2000), "In the Mind's Ear: The Semantic Extension of Perception Verbs in Australian Languages", Language, vol. 76, no. 3, p. 546-592.

Gilbert É. (1987), May, must, can et les opérations énonciatives, Gap, Ophrys.

Hellerstedt M., Peltola R. (2019), “Le chemin de l'audible: la structuration dynamique de la perception par les verbes höras (suédois) et kuulua (finnois) 'être audible”, Syntaxe \& Sémantique, no. 20.

Huumo T. (2010), "Is Perception a Directional Relationship? On Directionality and Its Motivation in Finnish Expressions of Sensory Perception", Linguistics, vol. 48, no. 1, p. 49-97.

Ibarretxe-Antuñano I. (2013), "The Power of the Senses and the Role of Culture in Metaphor and Language", in Sensuous Cognition: Explorations into Human Sentience: Imagination, (E)motion and Perception, R. Caballero, J. E. Díaz Vera (eds.), Berlin - Boston, De Gruyter Mouton, p. 109-133.

JęDRZejowski Ł., Staniewski P. (eds.) (forthc.), The Linguistics of Olfaction. (Typological Studies in Language), Amsterdam, J. Benjamins.

Karlsson F. (2008), Finnish. An Essential Grammar, $2^{\text {nd }}$ ed., London - New York, Routledge. 
Koptjevskaja-Tамm M. (2015), "Introducing the Linguistics of Temperature", in The Linguistics of Temperature, M. Koptjevskaja-Tamm (ed.), Amsterdam - Philadelphia, J. Benjamins, p. 1-40.

Levshina N. (2016), "Verbs of Letting in Germanic and Romance Languages: A Quantitative Investigation Based on a Parallel Corpus of Film Subtitles", Languages in Contrast, vol. 16, no. 1, p. 84-117.

Majid A., Burenhult N. (2014), "Odors Are Expressible in Language as Long as You Speak the Right Language”, Cognition, vol. 130, no. 2, p. 266-270.

Majid A., Burenhult N., Stensmyr M., Valk J. de, Hansson B. S. (2018a), "Olfactory Language and Abstraction across Cultures", Philosophical Transactions of the Royal Society B, on line: https://royalsocietypublishing. org/doi/10.1098/rstb.2017.0139.

Majid A., Roberts S. G., Cilissen L., Emmorey K., Nicodemus B., O’Grady L., Woll B., Lelan B., Sousa H. de, Cansler B. L., Shayan S., Vos C. de, Senft G., Enfield N. J., Razak R. A., Fedden S., Tufvesson S., Dingemanse M., Ozturk O., Brown P., Hill C., Le Guen O., Hirtzel V., Gijn R. van, Sicoli M. A., Levinson S. C. (2018b), "Differential Coding of Perception in the World's Languages", Proceedings of the National Academy of Sciences of the United States of America, vol. 115, no. 45, p. 11369-11376.

Maslova E. (2004), "A Universal Constraint on the Sensory Lexicon, Or When Hear Can Mean 'See'?”, in Tipologičeskie obosnovanija v grammatike: $k$ 70-letiju professora Xrakovskogo V.S., A. P. Volodin (ed.), Moscow, Znak, p. 300-312.

Nakagawa H. (2012), “The Importance of TASTE Verbs in Some Khoe Languages”, Linguistics, vol. 50, no. 3, p. 395-420.

Rawoens G. (2008), Kausativa verbkonstruktioner i svenskan och nederländskan: en korpusbaserad syntaktisk-semantisk undersökning, Gothenburg, Göteborgs universitet.

Rey A. (ed.) (2010), Dictionnaire historique de la langue française, Paris, Le Robert.

Reznikova T., Rakhilina E., Bonch-Osmolovskaya A. (2012), “Towards a Typology of Pain Predicates", Linguistics, vol. 50, no. 3, p. 421-465.

San Roque L., Kendrick K. H., Norcliffe E., Brown P., Defina R., Dingemanse M., Dirksmeyer T., Enfield N. J., Floyd S., Hammond J., Rossi G., Tufvesson S., Putten S. van, Majid A. (2015), "Vision Verbs Dominate in Conversation across Cultures, But the Ranking of Non-Visual Verbs Varies”, Cognitive Linguistics, vol. 26, no. 1, p. 31-60. 
San Roque L., Kendrick K. H., Norcliffe E., Majid A. (2018), “Universal Meaning Extensions of Perception Verbs Are Grounded in Interaction", Cognitive Linguistics, vol. 29, no. 3, p. 371-406.

Snell-Hornby M. (1983), Verb-Descriptivity in German and English. A Contrastive Study in Semantic Fields, Heidelberg, Carl Winter Universitätsverlag.

Staniewski P., GoŁębiowski A. (forthc.), "To What Extent Can SourceBased Olfactory Verbs Be Classified as Copulas? - The Case of German and Polish", to appear in Jędrzejowski \& Staniewski (eds.).

Stokes D., Biggs S. (2015), "The Dominance of the Visual”, in Perception and Its Modalities, D. Stokes, M. Matthen, S. Biggs (eds.), Oxford, Oxford University Press, p. 350-378.

Strik Lievers F., Winter B. (2018), “Sensory Language across Lexical Categories”, Lingua, no. 204, p. 45-61.

Tegelberg E. (2000), Från svenska till franska, Lund, Studentlitteratur.

Viberg Å. (1983), “The Verbs of Perception: A Typological Study”, Linguistics, vol. 21, no. 1, p. 123-162.

Viberg Å. (2001), “The Verbs of Perception”, in Language Typology and Language Universals. An International Handbook, M. Haspelmath, E. König, W. Oesterreicher, W. Raible (eds.), Berlin - New York, W. de Gruyter, vol. II, p. 1294-1309.

Viberg Å. (2008), "Swedish Verbs of Perception from a Typological and Contrastive Perspective", in Languages and Cultures in Contrast and Comparison, M. de los Ángeles Gómez González, J. L. Mackenzie, E. M. González-Álvarez (eds.), Amsterdam - Philadelphia, J. Benjamins (Pragmatics and Beyond New Series; 175), p. 123-172.

Viberg Å. (2009), “The Meaning Patterns of Swedish Låta 'Sound'; 'Let'. A Corpus-Based Contrastive Study", in Mélanges plurilingues offerts à Suzanne Schlyter à l'occasion de son $65^{e}$ anniversaire, P. Bernardini, V. Egerland, J. Granfeldt (eds.), Lunds, Språk- och Litteraturcentrum Romanska (Études romanes de Lund; 85), p. 455-480.

Viberg Å. (2012), "Basic Verbs in Typological Perspective”, in Le verbe en verve. Réflexions sur la syntaxe et la sémantique verbales, $M$. Van Peteghem, P. Lauwers, E. Tobbak, A. Demol, L. De Wilde (eds.), Gent, Academia Press, p. 255-273.

Viberg Å. (2013), "Posture Verbs. A Multilingual Contrastive Study”, Languages in Contrast, vol. 13, no. 2, p. 139-169.

Viberg Å. (2015), "Sensation, Perception and Cognition. Swedish in a Typological-Contrastive Perspective", Functions of Language, vol. 22, no. 1, p. 96-131. 
Viberg Å. (forthc.), "Why Is Smell Special? A Case Study of a European Language: Swedish", to appear in Jędrzejowski \& Staniewski (eds.).

Vinay J.-P., DARbelnet J. ([1958] 11995), Comparative Stylistics for French and English, J. C. Sager (trad.), Amsterdam - Philadelphia, J. Benjamins.

WäLchli B. (2016), "Non-Specific, Specific and Obscured Perception Verbs in Baltic Languages", Baltic Linguistics, no. 7, p. 53-135.

Whiтt R. J. (2010), Evidentiality and Perception Verbs in English and German, Bern, P. Lang.

Winter B., Perlman M., Majid A. (2018), "Vision Dominates in Perceptual Language: English Sensory Vocabulary is Optimized for Usage”, Cognition, no. 179 , p. $213-220$.

\section{Corpus $^{2}$}

CL: Läckberg C. (2004), Isprinsessan, Stockholm, Bokförlaget Forum.

HN: Nesser H. (1993), Det grovmaskiga nätet, Stockholm, Albert Bonniers förlag.

JM: Myrdal J. (1963), Rapport från kinesisk by, Stockholm, Norstedts förlag.

KE: Ekman K. (1993), Händelser vid vatten, Stockholm, Albert Bonniers förlag. KÖ: Östergren K. (1980), Gentlemen, Stockholm, Albert Bonniers förlag.

LM: Marklund L. (1998), Sprängaren, Stockholm, Ordupplaget.

MN: Niemi M. (2000), Populärmusik från Vittula, Stockholm, Norstedts förlag.

PCJ: Jersild P. C. (1976), Barnens ö, Stockholm, Albert Bonniers förlag.

PCJ2: Jersild P. C. (1980), En levande själ, Stockholm, Albert Bonniers förlag.

POE: Enquist P. O. (1991), Kapten Nemos bibliotek, Stockholm, Norstedts förlag.

SL: Larsson S. (2005), Män som hatar kvinnor, Stockholm, Norstedts förlag.

TL: Lindgren T. (2002), Pölsan, Stockholm, Norstedts förlag.

2. The present study is based on 22 Swedish original works in the Multilingual Parallel Corpus (MPC). Below is the list of the codes for the texts quoted in this article. For a complete list, see Viberg (2013), Appendix 1. 